\title{
A 2.5 year's source apportionment study of black carbon from wood burning and fossil fuel combustion at urban and rural sites in Switzerland
}

\author{
H. Herich, C. Hueglin, and B. Buchmann \\ Empa, Swiss Federal Laboratories for Materials Science and Technology, Laboratory for Air Pollution and Environmental \\ Technology, Duebendorf, Switzerland
}

Received: 7 October 2010 - Published in Atmos. Meas. Tech. Discuss.: 24 November 2010

Revised: 18 June 2011 - Accepted: 5 July 2011 - Published: 19 July 2011

\begin{abstract}
The contributions of fossil fuel (FF) and wood burning (WB) emissions to black carbon (BC) have been investigated in the recent past by analysis of multi-wavelength aethalometer data. This approach utilizes the stronger light absorption of WB aerosols in the near ultraviolet compared to the light absorption of aerosols from FF combustion.

Here we present 2.5 years of seven-wavelength aethalometer data from one urban and two rural background sites in Switzerland measured from 2008-2010. The contribution of $\mathrm{WB}$ and $\mathrm{FF}$ to $\mathrm{BC}$ was directly determined from the aerosol absorption coefficients of FF and WB aerosols which were calculated by using confirmed Ångstrom exponents and aerosol light absorption cross-sections that were determined for all sites. Reasonable separation of total BC into contributions from FF and WB was achieved for all sites and seasons. The obtained WB contributions to BC are well correlated with measured concentrations of levoglucosan and potassium while $\mathrm{FF}$ contributions to $\mathrm{BC}$ correlate nicely with $\mathrm{NO}_{\mathrm{x}}$. These findings support our approach and show that the applied source apportionment of $\mathrm{BC}$ is well applicable for long-term data sets.

During winter, we found that $\mathrm{BC}$ from WB contributes on average $24-33 \%$ to total $\mathrm{BC}$ at the considered measurement sites. This is a noticeable high fraction as the contribution of wood burning to the total final energy consumption is in Switzerland less than $4 \%$.
\end{abstract}

\section{Correspondence to: $\mathrm{H}$. Herich}

(hanna.herich@empa.ch)

\section{Introduction}

Atmospheric aerosol particles affect chemical, microphysi$\mathrm{cal}$, and radiative atmospheric processes. They are important when considering both the natural and the anthropogenic climate forcing (Forster et al., 2007). An abundant constituent in atmospheric aerosols is carbonaceous matter $(\mathrm{CM})$, which is composed of black carbon (BC) and organic carbon (OC). $\mathrm{BC}$ is the light absorbing part of carbonaceous material, which has a wavelength independent imaginary part of the refractive index. It is commonly referred to as soot. Compared to other aerosol constituents BC has very different optical and radiative properties, contributing significantly to current global warming (Jacobson, 2001, 2010; Forster et al., 2007; Ramanathan and Carmichael, 2008).

Besides their effects on the Earth's radiation budget, fine carbonaceous particles have been found to cause serious health effects as they penetrate into the human respiratory system (Oberdorster et al., 2002; Jerrett et al., 2005; Kennedy, 2007). Epidemiologic studies associated BC in particular with respiratory health effects in children and with cardiovascular diseases (Peters et al., 2000; Gauderman et al., 2004).

The major emission sources of soot particles in large parts of Europe and Switzerland are diesel engines and incomplete biomass burning. Especially in winter, wood combustion from domestic heating has been found to be a major contributor to air pollution in residential areas (Szidat et al., 2007; Lanz et al., 2008). Given that wood burning (WB) is a $\mathrm{CO}_{2}$ neutral energy source its impact on air quality is likely to become more and more relevant in the coming years.

Published by Copernicus Publications on behalf of the European Geosciences Union. 
Table 1. Measurements performed at the Zurich-Kaserne (ZUE), Payerne (PAY) and Magadino-Cadenazzo (MAG) sites.

\begin{tabular}{|c|c|c|c|c|c|}
\hline Site & $\begin{array}{l}\mathrm{AE} \\
10 \min -b_{\mathrm{abs}}(\lambda) \\
\text { in } \mathrm{PM}_{2.5}\end{array}$ & $\begin{array}{l}\text { OCEC analyzer } \\
3 \mathrm{~h}-\mathrm{OC} / \mathrm{EC} \\
\text { in } \mathrm{PM}_{2.5} \\
\text { (every } 12 \text { th day) }\end{array}$ & $\begin{array}{l}\text { High vol. sampler } \\
24 \mathrm{~h}-\mathrm{OC} / \mathrm{EC} \\
\text { in } \mathrm{PM}_{2.5} \\
\text { (every 4th day) }\end{array}$ & $\begin{array}{l}\text { High vol. sampler } \\
\text { Potassium } \\
\text { in } \mathrm{PM}_{10} \\
\text { (weekly samples) }\end{array}$ & $\begin{array}{l}\text { Low vol. sampler } \\
\text { Levoglucosan } \\
\text { in } \mathrm{PM}_{10}\end{array}$ \\
\hline ZUE & Apr 2009-Oct 2010 & & Mar 2008-Dec 2009 & & \\
\hline PAY & Mar 2008-Oct 2010 & Mar 2009-Mar 2010 & Mar 2008-Dec 2009 & Aug 2008-Jul 2009 & $\begin{array}{l}\text { Sep-Oct } 2008 \text { and } \\
\text { Feb-Mar } 2009\end{array}$ \\
\hline MAG & Mar 2008-Oct 2010 & & $\begin{array}{l}\text { Mar 2008-Dec } 2009 \\
\text { (in } \mathrm{PM}_{10} \text { ) }\end{array}$ & Aug 2008-Jul 2009 & \\
\hline
\end{tabular}

Several commercial instruments are available for the determination of $\mathrm{BC}$ in particulate matter (PM). In this study, the aethalometer (AE, Hansen et al., 1984) was used for continuous measurement of $\mathrm{BC}$. The working principle of an $\mathrm{AE}$ is the following: aerosols are collected on a quartz fibre filter and illuminated with light. The aerosol absorption coefficient $b_{\mathrm{abs}}$ is then calculated from the measured light attenuation. Corrections of the measured light attenuation artefacts such as multiple scattering and so called "shadowing" are typically applied (Weingartner et al., 2003; Collaud Coen et al., 2010 and references therein). However, note that further possible systematic errors need to be considered for correct determination of $b_{\text {abs }}$ using a filter based method (Subramanian et al., 2007). The BC mass concentration is obtained from $b_{\text {abs }}$ divided by the mass specific aerosol light absorption cross section $\sigma_{\text {abs }}$. Newer AE instruments operate at several wavelengths ranging from the near-ultraviolet (UV) to the near-infrared (IR). The wavelength dependence of the aerosol absorption coefficient $\mathrm{b}_{a b s}$ can be described by the power law $b_{\text {abs }}(\lambda) \sim \lambda^{-\alpha}$, where $\lambda$ is the wavelength of the light beam and $\alpha$ is the Angstrom exponent. The spectral dependence allows distinguishing carbonaceous aerosols from different sources. This is because of light absorbing OC which in contrast to BC exhibits a stronger absorption at shorter wavelengths (Andreae and Gelencser, 2006; Lukács et al., 2007; Moosmüller et al., 2009). For example, biomass burning aerosols are known to contain a significant number of light absorbing organic substances or brown-carbon and have a strong spectral dependence $(\alpha>2)$ while emissions from diesel engines contain primarily $\mathrm{BC}$ and have a weak spectral dependence $(\alpha \sim 1)$ (e.g. Kirchstetter et al., 2004; Clarke et al., 2007). Under certain conditions the range of Ångstrom exponents for brown carbon and BC may possibly be wider (Lack and Cappa, 2010).

In the past multiple wavelength AEs were deployed to determine the contributions of traffic and WB to total CM. This was accomplished with a source apportionment model introduced by Sandradewi et al. (2008a). Sandradewi et al. (2008a) collected AE data in winter during a measurement campaign in an alpine valley where WB from domestic heating and traffic emissions were the dominating sources of CM. Linear regression of CM against the aerosol absorption coefficient of FF combustion aerosols in the infrared $(950 \mathrm{~nm})$ and the aerosol absorption coefficient of WB aerosols in the UV $(470 \mathrm{~nm})$ was proposed for source apportionment. The authors estimated an average contribution of WB to total CM of $88 \%$. In a recent study, Favez et al. (2009) applied the same approach to data sampled in urban Paris during a winter field campaign. The authors determined regression coefficients similar to Sandradewi et al. (2008a) and estimated the average contribution of WB to total CM to be $46 \%$.

In this study we applied the AE model to data collected from 2008 to 2010 at three measurement sites in Switzerland. To our knowledge this is the first long-term source apportionment study using this modelling approach. In a first step we focused on CM. Sensitivity tests for different regression models and for various Ångstrom exponents were performed. It was found that the regression modelling approach is not suitable for our long-term datasets because of significant fractions of $\mathrm{CM}$ resulting from sources and processes other than FF and WB. Thus in a second step we focused on the contributions of FF combustion and WB to BC which was calculated directly from $b_{\mathrm{abs}}$ by the use of site specific $\sigma_{\mathrm{abs}}$ values. We determined the fractions of $\mathrm{BC}$ resulting from emissions of FF combustion and $\mathrm{WB}$ on a seasonal and a daily basis and compared our findings with measured concentrations of tracers for WB (levoglucosan and potassium) and with estimated elemental carbon emitted by WB as obtained from a receptor modelling study.

\section{Experimental procedure}

\subsection{Sampling sites and instrumentation}

Measurements were performed at one urban and two rural stations of the Swiss National Air Pollution Monitoring Network (NABEL) (EMPA, 2010) from 2008 to 2010 as listed in Table 1. The NABEL station Zurich-Kaserne (ZUE) is 
an urban background site located in a courtyard in the city centre of Zurich $\left(47^{\circ} 22^{\prime} \mathrm{N}, 8^{\circ} 32^{\prime} \mathrm{E}, 410 \mathrm{~m}\right.$ a.s.l.). The location is surrounded by roads with rather low traffic and is not affected by major emissions from industries. The stations Payerne (PAY) and Magadino-Cadenazzo (MAG) are rural sites. PAY is located in the western part of the Swiss Plateau one kilometre outside of Payerne, a small city with 8000 inhabitants. The site is surrounded by agricultural land (grassland and crops), forests and small villages $\left(46^{\circ} 48^{\prime} \mathrm{N}\right.$, $6^{\circ} 56^{\prime} \mathrm{E}, 489 \mathrm{~m}$ a.s.l.). The MAG site is located south of the Alps in the Magadino plane close to the Lago Maggiore $\left(46^{\circ} 09^{\prime} \mathrm{N}, 8^{\circ} 56^{\prime} \mathrm{E}, 204 \mathrm{~m}\right.$ a.s.l. $)$ and about two kilometres outside of Cadenazzo, a village with 2000 inhabitants.

Multiple-wavelength AEs (Magee Scientific, USA, model AE31) were deployed at all measurement sites for determination of BC. All instruments were equipped with $\mathrm{PM}_{2.5}$ inlets. The AE continuously detects the aerosol attenuation coefficient of the collected aerosol particles $b_{\mathrm{ATN}}(\lambda)$ at seven wavelengths $\lambda(370,470,520,590,660,880$ and $950 \mathrm{~nm})$ with a time resolution of 5 minutes. The calculation of the aerosol absorption coefficients $b_{\text {abs }}(\lambda)$ was done according to the data correction procedure by Weingartner et al. (2003)

$b_{\mathrm{abs}}(\lambda)=\frac{b_{\mathrm{abs}}(\lambda)}{C \cdot R\left(\mathrm{ATN}_{\lambda}\right)}$.

A constant factor $C=2.14$ is applied to correct for multiple scattering of the incident light at the filter fibres in an unloaded filter. This constant factor was determined by Weingartner et al. (2003) in studies using pure soot particles with known absorption coefficient. In order to correct for increasing light attenuation due to accumulating particles in the filter (shadowing effect) an empirical function of the measured light attenuation at the different wavelength $\operatorname{ATN}_{\lambda}$ is used

$R\left(\operatorname{ATN}_{\lambda}\right)=\left(\frac{1}{f_{\lambda}}-1\right) \cdot \frac{\ln \left(\operatorname{ATN}_{\lambda}\right)-\ln (10)}{\ln (50)-\ln (10)}+1$.

The $f_{\lambda}$ in Eq. (2) are constants, here we used the mean values of the $f_{\lambda}$ 's found by Sandradewi et al. (2008b) during campaigns in summer and winter at an rural site in a Swiss alpine valley.

Further systematic errors in filter based aerosol light absorption measurements are possible (Subramanian et al., 2007), but neglected here. This has however no effect on the presented results on the source apportionment of $\mathrm{BC}$, because systematic errors in the aerosol absorption coefficients would be compensated by the obtained values for $\sigma_{\mathrm{abs}}$.

Parallel to the measurement of $b_{\mathrm{abs}}(\lambda)$ at the three sites, daily $\mathrm{PM}_{2.5}$ and at MAG daily $\mathrm{PM}_{10}$ samples were collected at every twelfth day on quartz fibre filters (Pallflex Tissuquartz 2500QAT) using a high-volume sampler (Digitel DHA-80, $30 \mathrm{~m}^{3} \mathrm{~h}^{-1}$ flow rate). Punches of these $\mathrm{PM}_{2.5}$ and $\mathrm{PM}_{10}$ filter samples were analysed for organic and elemental carbon (OC and EC) by applying the thermal optical transmission method (TOT). The OCEC analyzer (Sunset
Table 2. Wavelength-dependent aerosol light absorption cross sections used in this study. Values were determined from the linear regression of $b_{\mathrm{abs}}(\lambda)$ against the concentration of elemental carbon in $\mathrm{PM}_{2.5}$ (for MAG in $\mathrm{PM}_{10}$ ). Note that the values for light absorption cross sections depend on the method used for determination of EC mass concentration.

\begin{tabular}{ccccc}
\hline$\lambda$ & $\begin{array}{c}\text { Manufacturer } \\
\sigma_{\text {abs }}(\lambda) \\
{\left[\mathrm{m}^{2} \mathrm{~g}^{-1}\right]}\end{array}$ & $\begin{array}{c}\text { PAY } \\
\sigma_{\text {abs }}(\lambda) \\
{\left[\mathrm{m}^{2} \mathrm{~g}^{-1}\right]}\end{array}$ & $\begin{array}{c}\text { MAG } \\
\sigma_{\text {abs }}(\lambda) \\
{\left[\mathrm{m}^{2} \mathrm{~g}^{-1}\right]}\end{array}$ & $\begin{array}{c}\text { ZUE } \\
\sigma_{\text {abs }}(\lambda) \\
{\left[\mathrm{m}^{2} \mathrm{~g}^{-1}\right]}\end{array}$ \\
\hline $370 \mathrm{~nm}$ & 30 & $37.3( \pm 2.2)$ & $35.1( \pm 2.2)$ & $26.2( \pm 7.5)$ \\
$470 \mathrm{~nm}$ & 23.6 & $27.4( \pm 1.3)$ & $22.9( \pm 1.2)$ & $20.5( \pm 5.8)$ \\
$520 \mathrm{~nm}$ & 21.3 & $23.8( \pm 1.2)$ & $19.5( \pm 1.1)$ & $17.5( \pm 5.2)$ \\
$590 \mathrm{~nm}$ & 18.8 & $20.8( \pm 1.0)$ & $16.4( \pm 1.1)$ & $15.2( \pm 4.4)$ \\
$660 \mathrm{~nm}$ & 16.8 & $18.5( \pm 0.9)$ & $14.4( \pm 0.8)$ & $14.0( \pm 4.3)$ \\
$880 \mathrm{~nm}$ & 12.6 & $13.2( \pm 0.8)$ & $9.9( \pm 0.6)$ & $10.0( \pm 3.1)$ \\
$950 \mathrm{~nm}$ & 11.7 & $11.8( \pm 0.6)$ & $8.8( \pm 0.5)$ & $9.3( \pm 2.8)$ \\
\hline
\end{tabular}

Laboratory Inc.) was operated with the EUSAAR2 temperature protocol (Cavalli et al., 2010).

The $\mathrm{BC}$ mass concentration is calculated from $b_{\text {abs }}(\lambda)$ divided by the wavelength dependent aerosol light absorption cross section $\sigma_{\mathrm{abs}}$, denoted as $\sigma_{\mathrm{abs}}(\lambda)$. Here we determined site specific $\sigma_{\mathrm{abs}}(\lambda)$ from the slope of the linear regression of the daily means of $b_{\mathrm{abs}}(\lambda)$ against the EC concentration. Linear regression models individually for different seasons indicate higher aerosol light absorption cross sections at the near-UV wavelengths $(370 \mathrm{~nm}$ and $470 \mathrm{~nm}$ ) during the cold season. However, the seasonal dependence of the light absorption cross section is not significant at the $95 \%$ confidence level, the number of data pairs for each season is currently too small. Therefore, light absorption cross sections were determined for data from all year, - the obtained coefficients of determination were $R^{2}>0.94$ (PAY), $R^{2}>0.68$ (ZUE) and $R^{2}>0.9$ (MAG). Table 2 summarizes the determined site specific values for $\sigma_{\text {abs }}(\lambda)$.

At PAY, OC and EC concentrations are additionally available as 3-hourly mean values from a semi-continuous OCEC analyzer (Sunset Laboratory Inc.; thermal optical transmission method, EUSAAR2 temperature protocol). This instrument was also equipped with a $\mathrm{PM}_{2.5}$ inlet.

Finally, measurements of potassium and levoglucosan in $\mathrm{PM}_{10}$ are available from PAY, potassium concentrations are also available in $\mathrm{PM}_{10}$ from MAG. The concentration of water soluble potassium was determined by ion-chromatography (Dionex IC 3000) after extraction of punches $\left(2.5 \mathrm{~cm}\right.$ diameter) of the daily $\mathrm{PM}_{2.5}(\mathrm{PAY})$ and $\mathrm{PM}_{10}$ filter samples (ZUE) in $40 \mathrm{ml}$ of nanopure water during $\approx 15 \mathrm{~h}$. Levoglucosan concentrations at PAY were determined by NILU as part of the intensive measurement periods of the European Monitoring and Evaluation Programme (EMEP) in fall 2008 and spring 2009. The applied method is described in Dye and Yttri (2005). 
Potassium concentrations were determined in daily $\mathrm{PM}_{10}$ samples collected at every fourth day from August 2008 to July 2009. Levoglucosan was determined in eight approximately weekly $\mathrm{PM}_{10}$ samples collected with a low volume sampler (Rupprecht and Patashnik, model Partisol FRM2000) in fall 2008 and spring 2009.

\subsection{The aethalometer model}

The AE model aims to quantify the contribution of fossil fuel (FF) and WB aerosol to the BC concentration. The model has been described in detail by Sandradewi et al. (2008a). Briefly, it relies on two assumptions (a) that during winter FF combustion and WB emissions from domestic heating are the dominating sources of $\mathrm{CM}$, and (b) that total ambient $\mathrm{CM}$ can be modelled by the light absorption of aerosols emitted by these two sources. The first assumption implies that the aerosol absorption coefficient $b_{\mathrm{abs}}(\lambda)$ at a given wavelength $\lambda$ can be expressed as the sum of the light absorption of aerosols emitted by these two sources:

$b_{\text {abs }}(\lambda)=b_{\text {absFF }}(\lambda)+b_{\text {absWB }}(\lambda)$.

$b_{\mathrm{absFF}}(\lambda)$ and $b_{\mathrm{absWB}}(\lambda)$ are the wavelength dependent aerosol absorption coefficient of BC from fossil fuel and wood burning emissions, respectively. Both quantities can be calculated from light absorption measurements if the spectral dependence (expressed by the Ångstrom exponent $\alpha$ ) for both sources are known. With given $\alpha_{\mathrm{FF}}$ and $\alpha_{\mathrm{WB}}$ and two different wavelength $\lambda_{1}$ and $\lambda_{2}$, the following equations apply:

$b_{\mathrm{absFF}}\left(\lambda_{1}\right) / b_{\mathrm{absFF}}\left(\lambda_{2}\right)=\left(\lambda_{1} / \lambda_{2}\right)^{-\alpha \mathrm{FF}}$

$b_{\text {absWB }}\left(\lambda_{1}\right) / b_{\text {absWB }}\left(\lambda_{2}\right)=\left(\lambda_{1} / \lambda_{2}\right)^{-\alpha \mathrm{WB}}$.

Light absorption measurements at $\lambda_{1}=470 \mathrm{~nm}$ and $\lambda_{2}=880 \mathrm{~nm}$ (or $\lambda_{2}=950 \mathrm{~nm}$ ) are used in this approach. This is due to the fact that $\mathrm{BC}$ from FF combustion has a weak dependence on wavelength whereas BC from WB shows enhanced absorption at shorter wavelength.

Equations (1) to (3) can be used to calculate $b_{\text {absFF }}(880 \mathrm{~nm})$ and $b_{\text {absWB }}(470 \mathrm{~nm})$. In the approach by Sandradewi et al. (2008a), the mass concentration of total carbonaceous matter was regressed against $b_{\mathrm{absFF}}(880 \mathrm{~nm})$ and $b_{\text {absWB }}(470 \mathrm{~nm})$ for determination of the contribution of fossil fuel combustion and wood burning to $\mathrm{CM}$,

$\mathrm{CM}=C_{1} \cdot b_{\mathrm{absFF}}(880 \mathrm{~nm})+C_{2} \cdot b_{\mathrm{absWB}}(470 \mathrm{~nm})$

with the parameters $C_{1}$ and $C_{2}$ relating the aerosol absorption coefficient to the total carbonaceous mass concentration.

In this study, the contributions of FF and WB to total $\mathrm{BC}$ $\left(\mathrm{BC}_{\mathrm{FF}}\right.$ and $\left.\mathrm{BC}_{\mathrm{WB}}\right)$ are also directly calculated by assuming that the light attenuation cross sections for aerosols from FF combustion and WB $\left(\sigma_{\mathrm{absFF}}(\lambda)\right.$ and $\left.\sigma_{\mathrm{absWB}}(\lambda)\right)$ can be represented by the average site specific $\sigma_{\mathrm{abs}}(\lambda)$ as indicated in Table 2. Consequently,

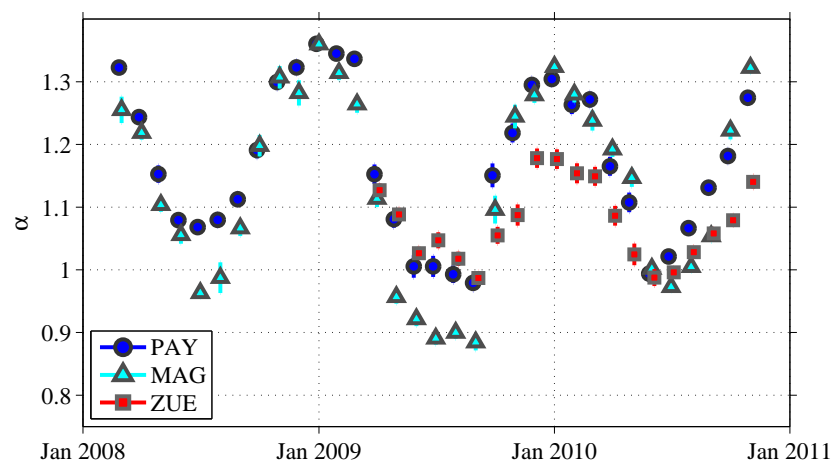

Fig. 1. Time series of the monthly mean Ångstrom exponent $\alpha$ at PAY, MAG and ZUE. Vertical lines indicate the uncertainty band of the estimated mean values.

$$
\begin{aligned}
\mathrm{BC}_{\mathrm{FF}} & =b_{\mathrm{absFF}}(880 \mathrm{~nm}) / \sigma_{\mathrm{abs}}(880 \mathrm{~nm}) \\
& \text { and } \mathrm{BC}_{\mathrm{WB}}=b_{\mathrm{absWB}}(470 \mathrm{~nm}) / \sigma_{\mathrm{abs}}(470 \mathrm{~nm}) .
\end{aligned}
$$

This simplification is justified by the absence of a seasonal cycle of the determined $\sigma_{\mathrm{abs}}(\lambda)$ and the high correlations of measured aerosol absorption coefficients and EC leading to rather small uncertainties of the average $\sigma_{\mathrm{abs}}(\lambda)$ (Table 2). Therefore, the varying impacts of sources and processes seem to have a small or negligible influence on $\sigma_{\mathrm{abs}}(\lambda)$. Thus this simplification seems not to introduce significant uncertainty or bias.

Note that the derived $\mathrm{BC}_{\mathrm{FF}}$ and $\mathrm{BC}_{\mathrm{WB}}$ are consistent with elemental carbon concentrations because the aerosol light absorption cross sections were calculated from EC analysis using the thermal optical transmission method.

\section{Results}

\subsection{Light absorption measurements}

For PAY, MAG and ZUE the Ångstrom exponent $\alpha$ was calculated over all seven wavelengths and for different time intervals. $\alpha$ was thus determined from power law fits of $b_{\text {abs }}(\lambda) / b_{\text {abs }}(950 \mathrm{~nm})$ as a function of the wavelength. Figure 1 shows time series for the monthly mean values of $\alpha$ from March 2008 to October 2010. A strong seasonal cycle of $\alpha$ can be observed at all sites, the Ångstrom exponent is higher during winter than during summer. This indicates that aerosols in winter contain more UV-absorbing material than in summer. During winter $\alpha$ is similar at the two rural sites PAY and MAG, mean values vary between 1.25 and 1.35. In summer MAG shows lower $\alpha$ values $(\sim 0.9 \pm 0.05)$ than PAY $(\sim 1.0 \pm 0.05)$. At both stations the observed $\alpha$ values were lower in 2009 compared to 2008 and 2010. For the urban background site ZUE the monthly $\alpha$ varies from 0.95 to 1.05 during summer, $\alpha$ is about 1.15 during winter.

Figure $2 \mathrm{a}$ and $\mathrm{b}$ show average diurnal cycles of $\alpha$ for summer (June-August) and for winter (December-February). In 

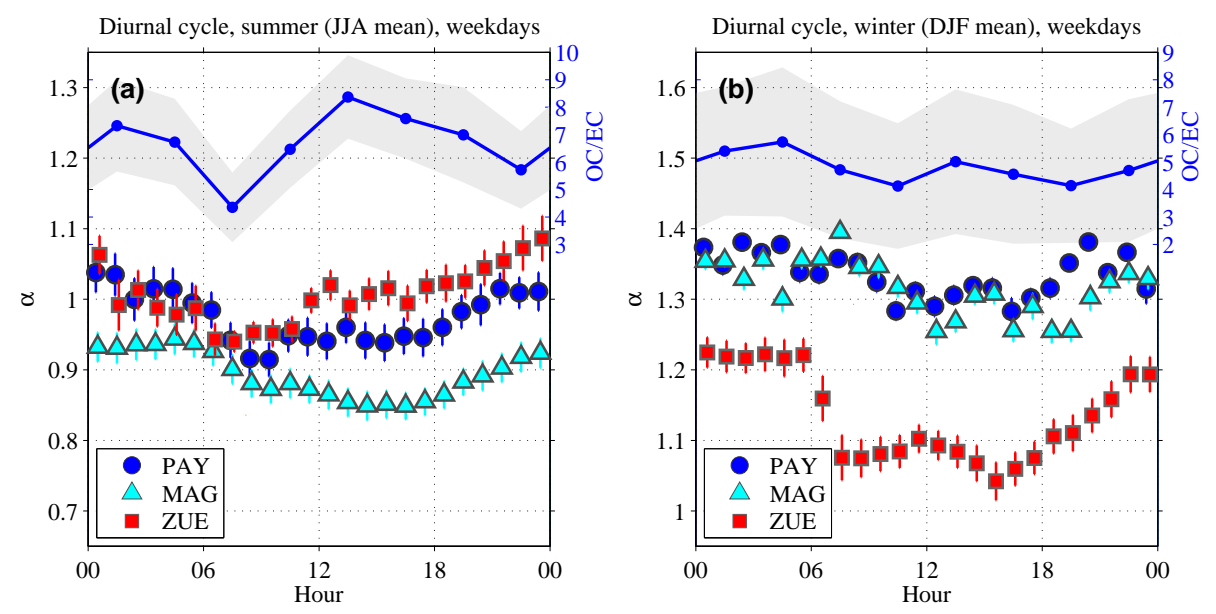

Fig. 2. Average diurnal cycle of hourly $\alpha$ at PAY, MAG and ZUE on weekdays during summer (June, July, August; left panel) and during winter (December, January, February; right panel). Vertical lines indicate the uncertainty band of the estimated mean values. For PAY the OC/EC ratio with one standard deviation band (grey area) is shown (3 hourly means, right axis).

both figures, $\alpha$ is shown as hourly values calculated from measurements that were taken on working days only. PAY and MAG show similar diurnal patterns during winter, where $\alpha$ varies between 1.35 during night and 1.25 during daytime. In winter $\alpha$ values close to 1.25 are observed during night at ZUE, during day $\alpha$ is less than 1.1 in the morning and close to 1.05 during the evening rush hours. At PAY $\alpha$ varies between about 1.0 (night) and about 0.9 (day) in summer. Lowest $\alpha$ values of 0.9 are observed during the morning rush hours. At MAG $\alpha$ varies from 0.85 to 0.95 during summer, lowest $\alpha$ values of $\approx 0.87$ are observed during the afternoon. In ZUE, $\alpha$ varies between $\approx 1.1$ (night) and $\approx 1.0$ (day) in summer and a daily minimum with $\alpha \approx 0.95$ occurs during morning rush hours.

The mean $\alpha$ values observed during winter are $\approx 1.3$ in $\mathrm{PAY}$ and MAG and $\approx 1.15$ in ZUE. These values are lower than what has been reported for biomass burning aerosols (e.g. Kirchstetter et al., 2004; Bergstrom et al., 2007) but very similar to values observed at populated and polluted sites during winter (Favez et al., 2009; Yang et al., 2009). The diurnal patterns show at all stations lowest $\alpha$ during daytime and especially during the morning rush hours. This indicates the influence of particulate matter emitted by road traffic.

Figure $2 \mathrm{a}$ and $\mathrm{b}$ include $\mathrm{OC} / \mathrm{EC}$ ratios derived from 3-hourly concentration measurements at PAY. The mean OC/EC ratio at PAY varies from 4 to 8 during summer with the daily minimum between 06:00 a.m. and 09:00 a.m. and the maximum from 12:00 p.m. to 03:00 p.m. During winter the variability of the OC/EC ratio is reduced, the observed OC/EC ratios vary between 4 and 6 .

During summer, Angstrom exponents less than 1 are observed at all measurement sites. Such low $\alpha$ values have been reported before (Gyawali et al., 2009 and references therein). Gyawali et al. (2009) show that values of $\alpha<1$ may occur for large aerosol particles and/or aerosol particles of certain shape and mixing state. For example, the authors attributed $\alpha<1$ to aerosol particles that consist of a collapsed soot core and a coating shell of organic and inorganic secondary aerosol. Especially in MAG where the lowest $\alpha$ values were observed during summer it is known from filter analyses that organic matter contributes on annual average $40 \%$ to the total $\mathrm{PM}_{10}$ mass (M. Gianini, personal communication, 2010). This is high compared to rural sites north of the alps.

At PAY, MAG and ZUE $\alpha$ values are in summer $\approx 0.9 \pm 0.1$ during the morning rush hours. At the same time the $\mathrm{OC} / \mathrm{EC}$ ratio at PAY is at a daily minimum. This observations point to an impact of road traffic emissions, we therefore attribute $\alpha \sim 0.9$ to BC from road traffic emissions. As discussed earlier, previous studies often reported values of $\alpha \sim 1$ for diesel soot experiments. However site specific traffic values may differ from the laboratory results. Our measurement stations are neither located nearby roadways nor directly situated close to other primary emission sources. Sampled traffic related particulate matter may have likely undergone some aging and may be collapsed or coated by the time the sampling site is reached. Here we choose the Ångstrom exponent $\alpha_{\mathrm{FF}}=0.9$. The absorption coefficients $\alpha_{\mathrm{WB}}=1.9$ is taken from literature (Sandradewi et al., 2008a).

\subsection{Application of the aethalometer model}

\subsubsection{Test of applicability}

Sandradewi et al. (2008a) estimated the contribution of FF and WB to carbonaceous matter by multiple linear regression according to Eq. (6). This approach implies that no other sources than FF combustion and WB and no relevant $\mathrm{CM}$ formation process (e.g. formation of secondary organic aerosols SOA) are present. This assumption might be adequate during winter and for certain locations as shown in 

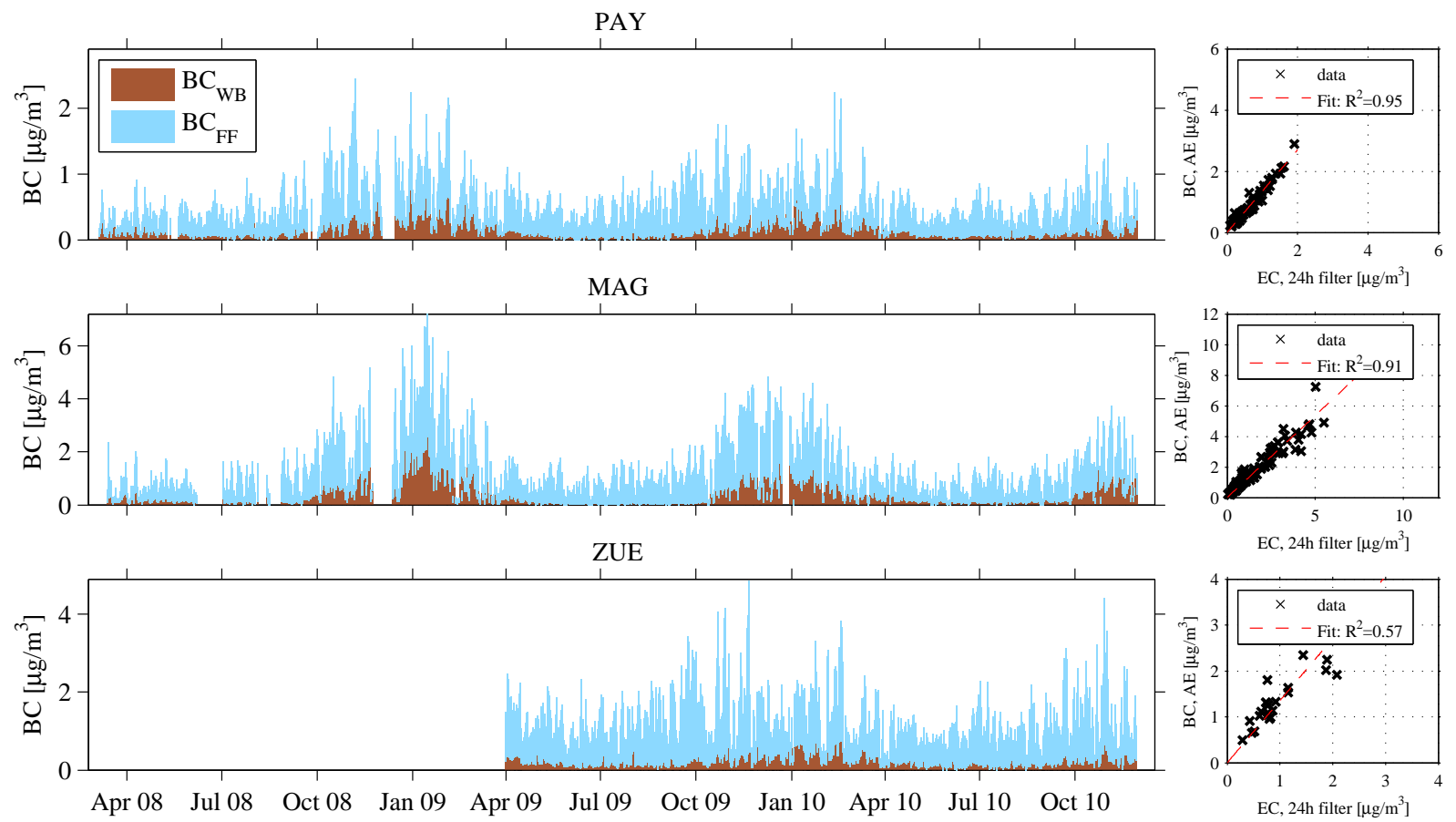

Fig. 3. Long-term pattern of $\mathrm{BC}_{\mathrm{FF}}$ and $\mathrm{BC}_{\mathrm{WB}}$ concentrations at PAY, MAG and ZUE (stacked). The scatter plots show the relationship between total daily BC and the daily EC concentration as determined with the thermal optical transmission method at every 4th day from 8 August to 9 July for the corresponding measurement site.

Sandradewi et al. (2008a). The approach was also applied by Favez et al. (2009), both studies found similar model parameters $C_{1}$ and $C_{2}$ for the short measurement campaigns performed during winter.

In a first try to test this source apportionment approach, we calculated total CM concentration from Equation (6) by using the values for $C_{1}$ and $C_{2}$ from (Sandradewi et al., 2008a; Favez et al., 2009) and $b_{\mathrm{absFF}}\left(\lambda_{1}\right)$ and $b_{\mathrm{abswB}}\left(\lambda_{2}\right)$ as derived from our measurements using Eqs. (3) to (5). We found systematic differences between calculated CM and CM determined from measured OC and EC (denoted as measured $\mathrm{CM}$ ). During summer the calculated CM was less than $50 \%$ of the measured CM which might result from large contributions by sources and processes other than FF combustion and WB during summer (e.g. SOA formation). During winter the calculated $\mathrm{CM}$ was about $25 \%$ larger than measured CM.

In a second try we performed regression modelling (with and without intercept, i.e. $C_{3}$ ) and with varying Ångstrom exponents $\alpha$ for estimating the contribution of FF combustion and WB to CM (Eq. 6). The modelling was performed for all available AE data as well as for winter data only.

This approach leads to a satisfactory agreement between measured and modelled CM, however, the standard error of the estimated $C_{1}, C_{2}$ (and where applicable $C_{3}$ ) is around $\pm 30 \%$ allowing no meaningful quantification of source contributions. In addition the sensitivity of $C_{1}$ and $C_{2}$ on the chosen Ångstrom exponents for aerosols from FF combustion and WB is high leading to a further increase in uncertainty.

Error estimates in the AE model are only sparsely discussed in literature. For example, Sandradewi et al. (2008a) and Favez et al. (2009) give no information about the uncertainty of the estimated parameters of the regression models. Also subsequent studies that include an intercept in the regression approach give only limited information about model errors (Sandradewi et al., 2008c; Favez et al., 2010).

Our investigations imply that the simple two sources approach expressed by Eq. (6) is not adequate for the longterm datasets from the three considered measurement sites because of significant contributions to $\mathrm{CM}$ from additional sources and processes.

\subsubsection{Source apportionment of BC}

As an alternative to the approach described in Sect. 3.2.1, we determined the contribution of FF combustion and WB to BC $\left(\mathrm{BC}_{\mathrm{FF}}\right.$ and $\left.\mathrm{BC}_{\mathrm{WB}}\right)$ at PAY, MAG and ZUE. As mentioned in Sect. 3.1 we used $\alpha_{\mathrm{FF}}=0.9$ and $\alpha_{\mathrm{WB}}=1.9$ to determine $b_{\mathrm{absFF}}$ and $b_{\mathrm{absWB}} . \mathrm{BC}_{\mathrm{FF}}$ and $\mathrm{BC}_{\mathrm{WB}}$ are directly determined from $b_{\text {absFF }}(880 \mathrm{~nm})$ and $b_{\text {absWB }}(470 \mathrm{~nm})$ using the site specific values for $\sigma_{\mathrm{abs}}(\lambda)$ (see Table 2).

Figure 3 shows the calculated $\mathrm{BC}_{\mathrm{FF}}$ and $\mathrm{BC}_{\mathrm{WB}}$ concentrations at the PAY, MAG and ZUE sites from April 2008 to October 2010 as daily mean values. For each measurement site the relationship between total $\mathrm{BC}$ and the $\mathrm{EC}$ concentrations 
Table 3. Contribution of $\mathrm{BC}_{\mathrm{FF}}$ and $\mathrm{BC} \mathrm{WB}_{\mathrm{B}}$ to total $\mathrm{BC}$ at the PAY, MAG and ZUE sites. Note that the given absolute $\mathrm{BC}$ values are consistent with EC as derived with the thermal-optical transmission method (TOT) using the EUSAAR 2 temperature protocol.

\begin{tabular}{|c|c|c|c|c|c|c|}
\hline & \multicolumn{2}{|c|}{ PAY (rural) } & \multicolumn{2}{|c|}{ MAG (rural) } & \multicolumn{2}{|c|}{ ZUE (urban) } \\
\hline & Summer & Winter & Summer & Winter & Summer & Winter \\
\hline $\mathrm{BC}_{\mathrm{FF}}(\%)$ & $94 \pm 10$ & $67 \pm 12$ & $98 \pm 7$ & $70 \pm 11$ & $90 \pm 8$ & $76 \pm 11$ \\
\hline $\mathrm{BC}_{\mathrm{WB}}(\%)$ & $6 \pm 10$ & $33 \pm 12$ & $2 \pm 7$ & $30 \pm 11$ & $10 \pm 8$ & $24 \pm 11$ \\
\hline Total BC $\left(\mu \mathrm{g} \mathrm{m}^{-3}\right)$ & $0.44 \pm 0.03$ & $0.78 \pm 0.05$ & $0.83 \pm 0.05$ & $2.29 \pm 0.14$ & $1.19 \pm 0.37$ & $1.54 \pm 0.48$ \\
\hline
\end{tabular}

in $\mathrm{PM}_{2.5}$ collected at every fourth day from August 2008 to July 2009 is also shown in a scatter plot. Table 3 shows seasonal mean concentrations of total $\mathrm{BC}$, and the contributions of $\mathrm{BC}_{\mathrm{FF}}$ and $\mathrm{BC}_{\mathrm{WB}}$ to total $\mathrm{BC}$ for winter and summer at all three stations. A stringent evaluation of the uncertainties in $\mathrm{BC}_{\mathrm{FF}}$ and $\mathrm{BC}_{\mathrm{WB}}$ is not possible, because different factors with unknown errors are contributing to the overall uncertainty. However, we assume that the uncertainties associated with selection of the Ångstrom exponents are dominating. In order to gain an impression about the approximate uncertainties, error margins are calculated by varying $\alpha_{\mathrm{FF}}$ and $\alpha_{\mathrm{WB}}$ within the range of plausible values $\left(\alpha_{\mathrm{FF}}\right.$ by \pm 0.1 and $\alpha_{\mathrm{WB}}$ by \pm 0.2$)$ and evaluation of the range of resulting $\mathrm{BC}_{\mathrm{FF}}$ and $\mathrm{BC}_{\mathrm{WB}}$.

In general, the total $\mathrm{BC}$ concentration is in winter at all stations substantially higher than in summer. On the one hand this can be explained by different meteorological conditions, e.g. in winter frequent temperature inversions lead to a reduced vertical mixing of the air and to an accumulation of air pollutants within the boundary layer. On the other hand emissions from WB have an additional impact on total BC concentrations during the cold season.

At the rural measurement site PAY the average BC concentration during winter (DJF mean) is $0.78 \pm 0.05 \mu \mathrm{g} \mathrm{m}{ }^{-3}$ with $33 \pm 12 \%$ of the total $\mathrm{BC}$ resulting from WB emissions. In summer (JJA mean) the $\mathrm{BC}$ concentration is on average $0.44 \pm 0.03 \mu \mathrm{g} \mathrm{m}^{-3}$ with WB contributions of $6 \pm 10 \%$. A similar seasonal pattern for BC can be observed in MAG. This rural site south of the alps shows highest $\mathrm{BC}$ concentrations during winter with a mean of $2.29 \pm 0.14 \mu \mathrm{g} \mathrm{m}^{-3}$ where $30 \pm 11 \%$ of total $\mathrm{BC}$ are estimated as $\mathrm{BC}_{\mathrm{WB}}$. During summer the mean $\mathrm{BC}$ concentration is $0.83 \pm 0.05 \mu \mathrm{g} \mathrm{m}^{-3}$, almost all of the BC during summer is found to result from emissions of FF combustion. The seasonal differences in $\mathrm{BC}$ concentrations are much lower at the urban background site ZUE compared to the rural sites. During summer the average BC concentration is $1.19 \pm 0.37 \mu \mathrm{g} \mathrm{m}^{-3}$ compared to $1.54 \pm 0.48 \mu \mathrm{g} \mathrm{m}^{-3}$ during winter. $\mathrm{BC}_{\mathrm{WB}}$ accounts for $10 \pm 8 \%$ of total $\mathrm{BC}$ during summer and $24 \pm 11 \%$ during winter. In 2002 and 2003, Szidat et al. (2006) performed ${ }^{14} \mathrm{C}$ analyses of elemental carbon in $\mathrm{PM}_{10}$ collected at the measurement site ZUE. The authors reported contributions of biomass burning to $\mathrm{EC}$ as $6 \pm 2 \%, 12 \pm 1 \%$, and $25 \pm 5 \%$ for $\mathrm{PM}_{10}$ samples from summer, spring and winter, respectively. These results are in good agreement with the WB contributions determined in this study.

Beside the seasonal averages, the contributions of FF combustion and WB to total $\mathrm{BC}$ have also been evaluated on a higher temporal resolution. Diurnal cycles of $\mathrm{BC}_{\mathrm{FF}}, \mathrm{BC}_{\mathrm{WB}}$ and total $\mathrm{BC}$ have been calculated as $3 \mathrm{~h}$ mean values and are shown in Fig. 4.

In summer mean concentrations of BC in PAY are generally below $0.5 \mu \mathrm{g} \mathrm{m}^{-3}$, both at weekdays and weekends, all of the $\mathrm{BC}$ is identified as $\mathrm{BC}_{\mathrm{FF}}$. $\mathrm{BC}$ concentrations are generally lowest during noon and afternoon which can be attributed to an increasing boundary layer height and corresponding aerosol dilution. During weekdays a maximum of total $\mathrm{BC}$ concentration occurs during morning rush hours. In winter the total $\mathrm{BC}$ concentrations at PAY is $0.8-1 \mu \mathrm{g} \mathrm{m}{ }^{-3}$ during weekdays with slightly elevated concentrations during rush hours. A BC concentration of $\approx 0.5 \mu \mathrm{g} \mathrm{m}{ }^{3}$ can be attributed to FF combustion during night and at weekends. At weekdays in winter the contribution of $\mathrm{BC}_{\mathrm{FF}}$ is $\approx 1 \mu \mathrm{g} \mathrm{m}{ }^{-3}$ during the morning and evening rush hours. The $\mathrm{BC}$ concentration in winter attributed to WB is both at weekdays and weekends relatively constant during the day and increases to $0.4 \mu \mathrm{g} \mathrm{m}^{3}$ in the evening.

In MAG the diurnal pattern of total $\mathrm{BC}$ is in summer similar to the $\mathrm{BC}$ pattern in PAY. Total $\mathrm{BC}$ can exclusively be attributed to $\mathrm{BC}_{\mathrm{FF}}$. During weekdays $\mathrm{BC}$ concentrations dominate during the morning rush hours. In winter, $\mathrm{BC}$ concentrations in MAG vary from $2.5-4.5 \mu \mathrm{g} \mathrm{m}^{-3}$ during weekdays and from $1.4-3.2 \mu \mathrm{g} \mathrm{m}^{-3}$ at weekends. During weekdays $\mathrm{BC}_{\mathrm{FF}}$ is $\approx 3.5 \mu \mathrm{g} \mathrm{m}^{-3}$ during the late morning and the evening rush hours. At weekends and at night $\mathrm{BC}_{\mathrm{FF}}$ varies from $1.0-2.0 \mu \mathrm{g} \mathrm{m}^{-3}$. During weekdays and weekends $\mathrm{BC}_{\mathrm{WB}}$ is lowest during the day, in the evening concentrations are increasing.

In ZUE the BC concentrations are in summer predominantly resulting from traffic emissions, the contribution of $\mathrm{BC}_{\mathrm{WB}}$ to total $\mathrm{BC}$ is negligible except for the evening hours at the weekends. This fraction can be attributed to local emissions from public fire and barbecue places close to the measurement site. In winter the total BC concentration in ZUE varies from $0.8-1.3 \mu \mathrm{g} \mathrm{m}^{-3}$ during weekends and from 1.2$1.7 \mu \mathrm{g} \mathrm{m}^{-3}$ during weekdays where highest concentrations 

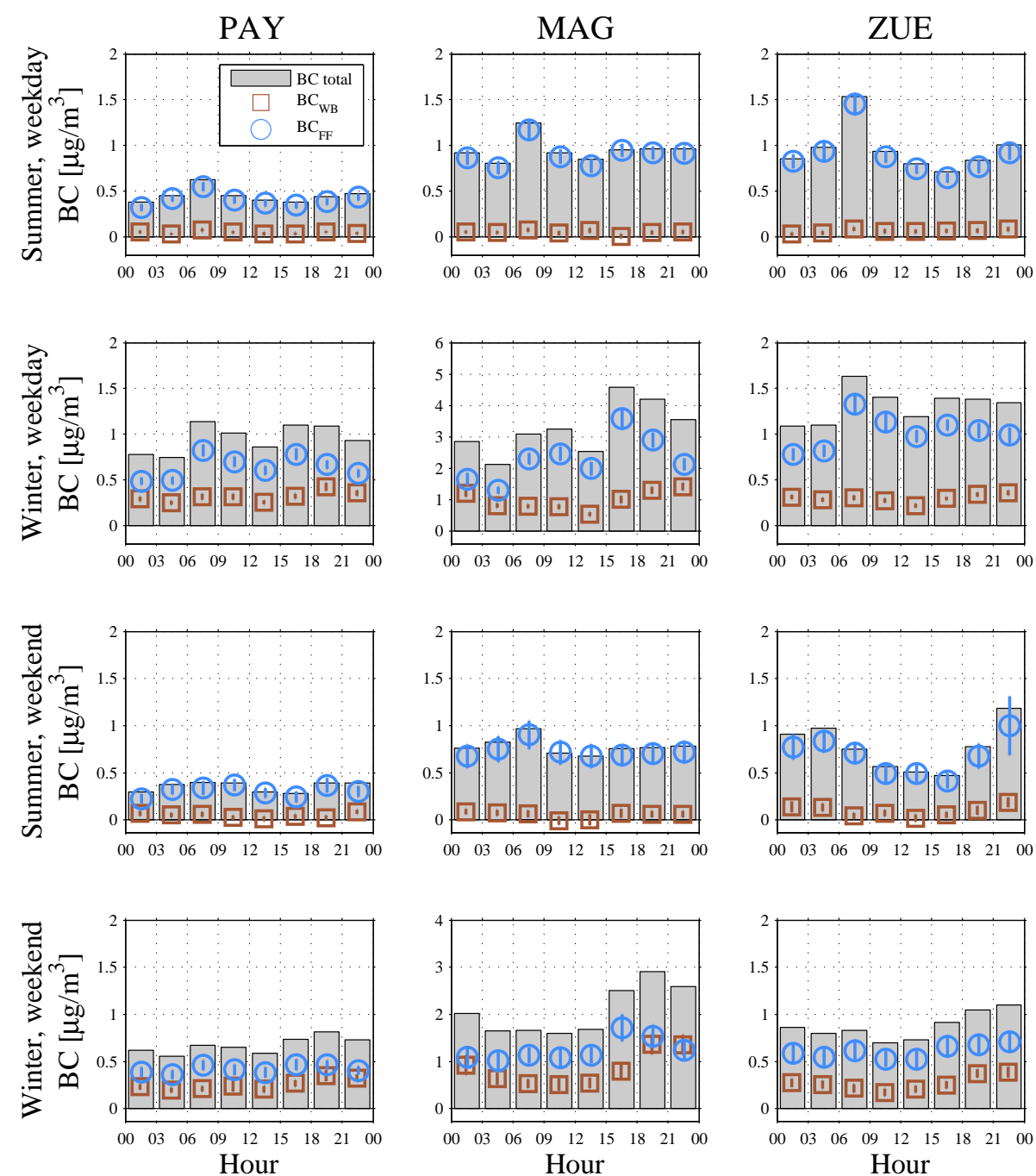

Fig. 4. Diurnal cycles of $\mathrm{BC}_{\mathrm{FF}}, \mathrm{BC}_{\mathrm{WB}}$ and total $\mathrm{BC}$ concentrations at PAY (column 1), MAG (column 2) and ZUE (column 3 ). The widths of the uncertainty bands for the estimated mean values are indicated as vertical lines in the symbols. At every site the data were filtered and analyzed for different conditions: weekdays in summer, weekdays in winter, weekend in summer and weekend in winter which are presented in row 1 to 4 , respectively.

occur during the morning and the evening. $\mathrm{BC}_{\mathrm{WB}}$ concentrations vary from $0.3-0.5 \mu \mathrm{g} \mathrm{m}^{3}$, both at weekdays and weekends where the higher concentrations occur during the evening hours.

In summary, the diurnal cycle of $\mathrm{BC}_{\mathrm{FF}}$ follows at all sites the expected pattern with highest concentrations during the rush hours when road traffic density is at maximum. On the other hand, the contribution of $\mathrm{BC}_{\mathrm{WB}}$ is only significant during winter. The diurnal cycles show at all sites increased concentrations during evenings and nights which can be explained by the typical operating time pattern of domestic heating appliances. The absolute concentrations and the found diurnal cycles of $\mathrm{BC}_{\mathrm{WB}}$ and $\mathrm{BC}_{\mathrm{FF}}$ indicate that the applied source apportionment approach gives reasonable results.
In the following we try a further verification of our approach by relating $\mathrm{BC}_{\mathrm{FF}}$ and $\mathrm{BC}_{\mathrm{WB}}$ to independent tracers for $\mathrm{FF}$ combustion and $\mathrm{WB}$, respectively.

\subsubsection{Comparison with auxiliary data}

For PAY the determined $\mathrm{BC}$ for $\mathrm{FF}$ combustion $\mathrm{BC}_{\mathrm{FF}}$ and for $\mathrm{WB}$ emissions $\mathrm{BC}_{\mathrm{WB}}$ are plotted against two markers for WB related aerosols, the water soluble fraction of potassium and levoglucosan. Figure 5a shows the relationship between daily potassium concentration and daily $\mathrm{BC}_{\mathrm{FF}}$ and $\mathrm{BC}_{\mathrm{WB}}$ at PAY. Daily $\mathrm{BC}_{\mathrm{WB}}$ and potassium are positively correlated $\left(R^{2}=0.77\right)$ while there is a much lower correlation between $\mathrm{BC}_{\mathrm{FF}}$ and potassium $\left(R^{2}=0.14\right)$. In Fig. $5 \mathrm{~b}$ the relationship between levoglucosan and $\mathrm{BC}_{\mathrm{FF}}$ and $\mathrm{BC}_{\mathrm{WB}}$ is shown for PAY. Each data point represents a mean concentration 

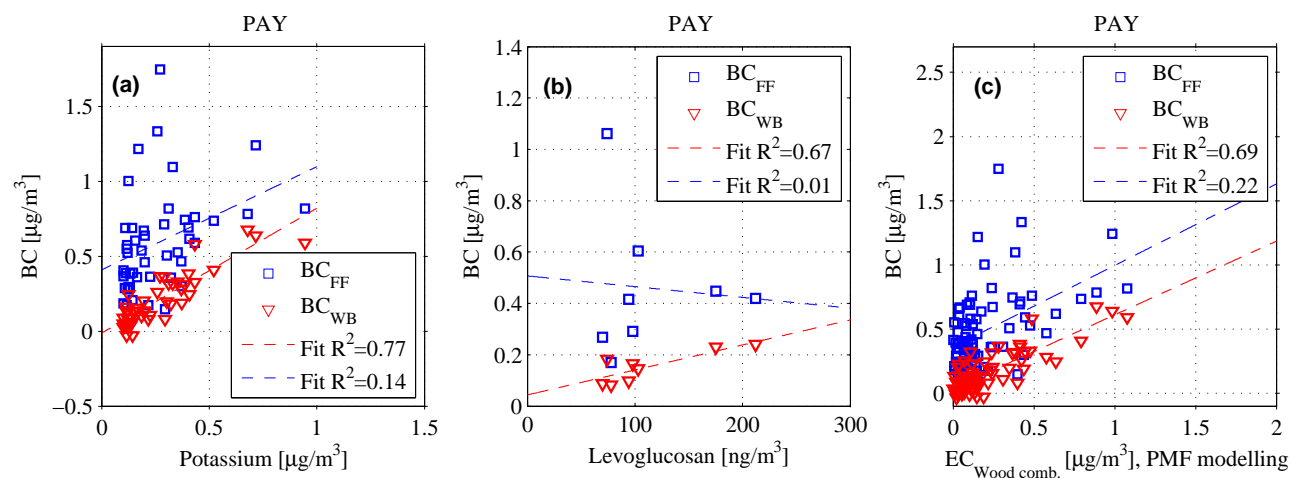

Fig. 5. Scatter plot of daily $\mathrm{BC}\left(\mathrm{BC}_{\mathrm{FF}}\right.$ and $\left.\mathrm{BC}_{\mathrm{WB}}\right)$ and potassium for $\mathrm{PAY}(\mathrm{a})$. Scatter plot of daily $\mathrm{BC}\left(\mathrm{BC}_{\mathrm{FF}}\right.$ and $\left.\mathrm{BC}_{\mathrm{WB}}\right)$ and levoglucosan in $\mathrm{PM}_{10}$ for PAY (b). Scatter plot of daily $\mathrm{BC}\left(\mathrm{BC}_{\mathrm{FF}}\right.$ and $\left.\mathrm{BC}_{\mathrm{WB}}\right)$ and $\mathrm{EC}$ from wood combustion emissions as derived from $\mathrm{PM}_{10}$ factor analytical modelling for PAY (c). All plots include linear regression lines.

over roughly a one week period. The calculated $\mathrm{BC}_{\mathrm{WB}}$ correlates well with levoglucosan, resulting in a high coefficient of determination $R^{2}=0.67$. There is no linear dependence between $\mathrm{BC}_{\mathrm{FF}}$ and levoglucosan $\left(R^{2}=0.01\right)$.

In addition, $\mathrm{BC}_{\mathrm{FF}}$ and $\mathrm{BC}_{\mathrm{WB}}$ were compared to $\mathrm{EC}$ source contributions as obtained in a $\mathrm{PM}_{10}$ source apportionment study (M. Gianini, personal communication, 2010) using a receptor modelling approach (positive matrix factorization PMF; Paatero and Tapper 1994). Figure $5 \mathrm{c}$ shows $\mathrm{BC}_{\mathrm{FF}}$ and $\mathrm{BC}_{\mathrm{WB}}$ versus the daily contribution of "wood combustion EC" for PAY as obtained by PMF. The correlation between $\mathrm{BC}_{\mathrm{WB}}$ and "wood combustion EC" is good resulting in a coefficient of determination $R^{2}=0.69$ while there is only little correlation between $\mathrm{BC}_{\mathrm{FF}}$ and "wood combustion EC" derived by PMF.

Also for $\mathrm{MAG} \mathrm{BC}_{\mathrm{FF}}$ and $\mathrm{BC}_{\mathrm{WB}}$ were plotted against potassium (Fig. 6a). Daily $\mathrm{BC}_{\mathrm{WB}}$ and potassium are positively correlated $\left(\mathrm{R}^{2}=0.72\right)$. The correlation between $\mathrm{BC}_{\mathrm{FF}}$ and potassium is clearly lower $\left(R^{2}=0.47\right)$. In Fig. $6 \mathrm{~b}, \mathrm{BC}_{\mathrm{FF}}$ and $\mathrm{BC}_{\mathrm{WB}}$ were compared to $\mathrm{EC}$ source contributions from PMF for MAG. Here, the correlation between $\mathrm{BC}_{\mathrm{WB}}$ and "wood combustion EC" results in a coefficient of determination $R^{2}=0.69$. There is again a clearly lower correlation between $\mathrm{BC}_{\mathrm{FF}}$ and "wood combustion" derived from PMF, $\left(R^{2}=0.32\right)$.

Note that for PAY and MAG, the findings for potassium and the modelled contribution of "wood combustion EC" are based on long-term measurements, the used data were collected during a whole year.

For the time period of the ZUE measurements neither potassium concentrations nor $\mathrm{PM}_{10}$ source apportionment results are available. However, in contrast to the rural sites PAY and MAG, the urban background site ZUE shows typically a high correlation between $\mathrm{BC}$ and nitrogen oxide $\mathrm{NO}_{\mathrm{x}}$ $\left(\mathrm{NO}_{\mathrm{x}}=\mathrm{NO}+\mathrm{NO}_{2}\right)$. Figure $7 \mathrm{a}$ and $\mathrm{b}$ show the relationship between daily $\mathrm{BC}_{\mathrm{FF}}$ and $\mathrm{BC}_{\mathrm{WB}}$ and $\mathrm{NO}_{\mathrm{x}}$ data (provided by NABEL) at ZUE for summer and winter, respectively. For both seasons the correlation between $\mathrm{BC}_{\mathrm{FF}}$ and $\mathrm{NO}_{\mathrm{x}}$ is good
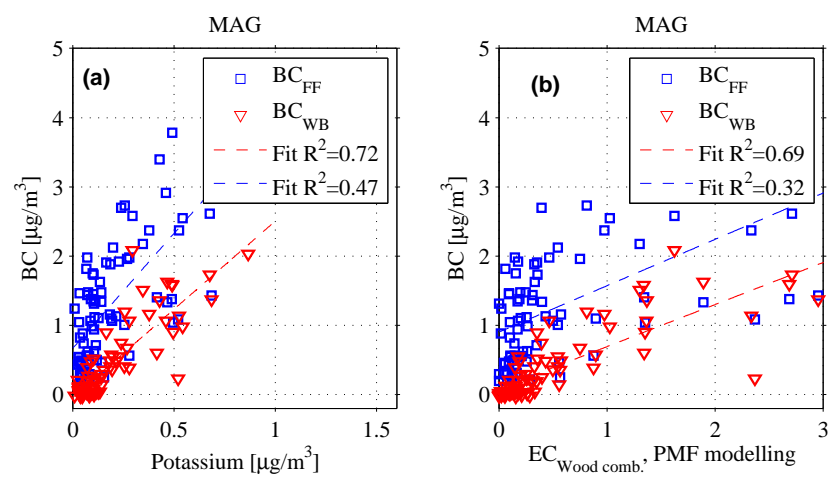

Fig. 6. Scatter plot of daily $\mathrm{BC}\left(\mathrm{BC}_{\mathrm{FF}}\right.$ and $\left.\mathrm{BC}_{\mathrm{WB}}\right)$ and potassium for MAG (a). Scatter plot of daily $\mathrm{BC}\left(\mathrm{BC}_{\mathrm{FF}}\right.$ and $\left.\mathrm{BC}_{\mathrm{WB}}\right)$ and $\mathrm{EC}$ from wood combustion emissions as derived from $\mathrm{PM}_{10}$ factor analytical modelling for MAG (b). Both plots include linear regression lines.

resulting in a high coefficient of determination $R^{2}=0.60$ (summer) and $R^{2}=0.83$ (winter). There is no correlation between $\mathrm{BC}_{\mathrm{WB}}$ and $\mathrm{NO}_{\mathrm{x}}$.

The comparisons show that there is in general a good agreement between the derived $\mathrm{BC}_{\mathrm{WB}}$ and $\mathrm{BC}_{\mathrm{FF}}$ with concentrations of WB and FF combustion indicators. These findings give confidence that the applied source apportionment approach for BC is well suited for long-term data sets.

Similar to the above described comparisons, Sandradewi et al. (2008c) found rather high correlations between the optical absorption of aerosols from FF combustion and WB and the fractions of EC that are of fossil and non-fossil origin. The latter was derived from analysis of ${ }^{14} \mathrm{C}$ in EC. The results from Sandradewi et al. (2008c) are therefore also indicating the high potential of data from multi-wavelength aethalometers for identification of the fractions of $\mathrm{BC}$ from $\mathrm{FF}$ combustion and WB. 

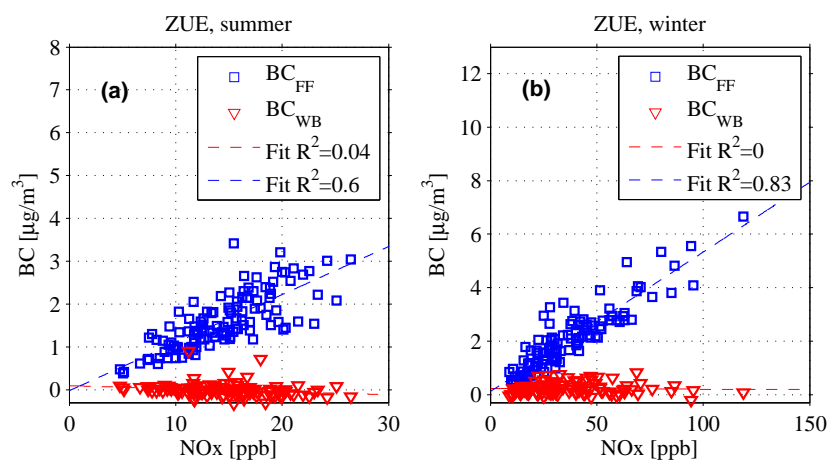

Fig. 7. Scatter plot of daily $\mathrm{BC}\left(\mathrm{BC}_{\mathrm{FF}}\right.$ and $\left.\mathrm{BC}_{\mathrm{WB}}\right)$ and $\mathrm{NO}_{\mathrm{x}}$ for ZUE for summer (a) and winter (b). Both plots include linear regression lines.

\section{Conclusions}

The $\mathrm{AE}$ is a robust and easy to use instrument for continuous optical determination of $\mathrm{BC}$ concentrations with temporal resolution of a few minutes. In this study, the measured $\mathrm{BC}$ concentrations are consistent with elemental carbon concentrations because the aerosol light absorption cross sections were calculated from EC analyses using the thermal optical transmission method.

We deployed multi-wavelength AE instruments at two rural (PAY and MAG) sites and one urban background site in Switzerland. The measurements were performed for up to 2.5 years. We found average black carbon concentrations of $0.43 \mu \mathrm{g} \mathrm{m}^{-3}$ at PAY, $0.8 \mu \mathrm{g} \mathrm{m}^{-3}$ at MAG and $0.99 \mu \mathrm{g} \mathrm{m}^{-3}$ at ZUE in summer and $0.8 \mu \mathrm{g} \mathrm{m}^{-3}$ at PAY, $3.03 \mu \mathrm{g} \mathrm{m}^{-3}$ at MAG and $1.34 \mu \mathrm{g} \mathrm{m}^{-3}$ at ZUE in winter.

Recent studies give reason that AE data may be used for source apportionment (Sandradewi et al., 2008a; Favez et al., 2009). But in these studies, the contribution of fossil fuel combustion and wood burning to the total carbonaceous aerosol was determined by analysis of $\mathrm{AE}$ data predominantly collected in winter during short-term measurement campaigns. Here we conclude that the proposed modelling approach is not applicable for long term datasets. This is likely due to significant fractions of the carbonaceous aerosol resulting from other sources and processes than FF combustion and WB.

In this study we focused on source apportionment of BC instead of total carbonaceous matter. The modified two sources approach fits very well to the measured $\mathrm{BC}$ concentrations. Separation of total $\mathrm{BC}$ into $\mathrm{BC}_{\mathrm{FF}}$ and $\mathrm{BC}_{\mathrm{WB}}$ was successful for all seasons and measurement sites. In winter, the determined mean fraction of $\mathrm{BC}_{\mathrm{WB}}$ to total $\mathrm{BC}$ was $33 \%$, $30 \%$ and $24 \%$ at PAY, MAG and ZUE respectively. These results are noticeable with respect to air quality control as wood combustion only contributed $3.9 \%$ to the total energy consumption in 2008 in Switzerland (Kaufmann, 2009).
It is interesting to note that the calculated contribution of $\mathrm{BC}_{\mathrm{WB}}$ is in excellent agreement with results reported for ZUE based on ${ }^{14} \mathrm{C}$ analyses (Szidat et al., 2006). Also, the obtained WB contributions to BC at PAY and MAG correlated well with measured concentrations of levoglucosan and water soluble potassium as well as with results from $\mathrm{PM}_{10}$ factor analytical modelling. In ZUE there is a good correlation between the obtained $\mathrm{BC}$ from $\mathrm{FF}$ combustion and $\mathrm{NO}_{\mathrm{x}}$. The latter findings support our approach and show that multiwavelength $\mathrm{AE}$ data are suitable for source apportionment of BC.

Acknowledgements. This study represents part of the research project IMBALANCE funded by the Competence Center Environment and Sustainability of the ETH Domain (CCES). Support from the Swiss Federal Office for the Environment (FOEN) is gratefully acknowledged. Many thanks to André Prévôt and Rudolf Weber for helpful discussions.

Edited by: A. J. M. Piters

\section{References}

Andreae, M. O. and Gelencsér, A.: Black carbon or brown carbon? The nature of light-absorbing carbonaceous aerosols, Atmos. Chem. Phys., 6, 3131-3148, doi:10.5194/acp-6-3131-2006, 2006.

Bergstrom, R. W., Pilewskie, P., Russell, P. B., Redemann, J., Bond, T. C., Quinn, P. K., and Sierau, B.: Spectral absorption properties of atmospheric aerosols, Atmos. Chem. Phys., 7, 5937-5943, doi:10.5194/acp-7-5937-2007, 2007.

Cavalli, F., Viana, M., Yttri, K. E., Genberg, J., and Putaud, J.P.: Toward a standardised thermal-optical protocol for measuring atmospheric organic and elemental carbon: the EUSAAR protocol, Atmos. Meas. Tech., 3, 79-89, doi:10.5194/amt-3-79-2010, 2010.

Clarke, A., McNaughton, C., Kapustin, V., Shinozuka, Y., Howell, S., Dibb, J., Zhou, J., Anderson, B., Brekhovskikh, V., Turner, H., and Pinkerton, M.: Biomass Burning and Pollution Aerosol over North America: Organic Components and their influence on Spectral Optical Properties and Humidification Response, J. Geophys. Res., 112, D12S18, doi:10.1029/2006JD007777, 2007.

Collaud Coen, M., Weingartner, E., Apituley, A., Ceburnis, D., Fierz-Schmidhauser, R., Flentje, H., Henzing, J. S., Jennings, S. G., Moerman, M., Petzold, A., Schmid, O., and Baltensperger, U.: Minimizing light absorption measurement artifacts of the Aethalometer: evaluation of five correction algorithms, Atmos. Meas. Tech., 3, 457-474, doi:10.5194/amt-3-457-2010, 2010.

Dye, C. and Yttri, K. E.: Determination of monosaccharide anhydrides in atmospheric aerosols by use of high-resolution mass spectrometry combined with high performance liquid chromatography, Anal. Chem., 77, 1853-1858, 2005.

EMPA: Technischer Bericht zum Nationalen Beobachtungsnetz für Luftfremdstoffe (NABEL), Swiss Federal Laboratories for Materials Testing and Research (EMPA), http://www.empa.ch/nabel, last access: July 2011, Dübendorf, Switzerland, 2010. 
Favez, O., Cachier, H., Sciare, J., Sarda-Estève, R., and Martinon, L.: Evidence for a significant contribution of wood burning aerosols to $\mathrm{PM}_{2.5}$ during the winter season in Paris, France, Atmos. Environ., 43, 3640-3644, 2009.

Favez, O., El Haddad, I., Piot, C., Boréave, A., Abidi, E., Marchand, N., Jaffrezo, J.-L., Besombes, J.-L., Personnaz, M.-B., Sciare, J., Wortham, H., George, C., and D'Anna, B.: Inter-comparison of source apportionment models for the estimation of wood burning aerosols during wintertime in an Alpine city (Grenoble, France), Atmos. Chem. Phys., 10, 5295-5314, doi:10.5194/acp-10-52952010, 2010.

Forster, P., Ramaswamy, V., Artaxo, P., Berntsen, T., Betts, R., Fahey, D. W., Haywood, J., Lean, J., Lowe, D. C., Myhre, G., Nganga, J., Prinn, R., Raga, G., Schulz, M., and Van Dorland, R.: Changes in atmospheric constituents and in radiative forcing, in Climate Change 2007: The Physical Science Basis - Contribution of Working Group I to the Fourth Assessment Report of the Intergovernmental Panel on Climate Change, edited by: Solomon, S., Qin, D., Manning, M., Chen, Z., Marquis, M., Averyt, K. B., Tignor, M., and Miller, H. L., Cambridge Univ. Press, New York, 129-233, 2007.

Gauderman, W. J., Avol, E., Gilliland, F., Vora, H., Duncan, T., Berhane, K., McConnell, R., Kuenzli, N., Lurmann, F., Rappaport, E., Margolis, H., Bates, D., and Peters, J.: The effect of air pollution on lung development from 10 to 18 years of age, N. Engl. J. Med., 351, 1057-1067, 2004.

Gyawali, M., Arnott, W. P., Lewis, K., and Moosmüller, H.: In situ aerosol optics in Reno, NV, USA during and after the summer 2008 California wildfires and the influence of absorbing and non-absorbing organic coatings on spectral light absorption, Atmos. Chem. Phys., 9, 8007-8015, doi:10.5194/acp-9-8007-2009, 2009.

Hansen, A. D. A., Rosen, H., and Novakov, T.: The aethalometer An instrument for the real-time measurement of optical absorption by aerosol particles, Sci. Total Environ., 36, 191-196, 1984.

Jacobson, M. Z.: Strong radiative heating due to the mixing state of black carbon on atmospheric aerosols, Nature, 409, 695-697, 2001.

Jacobson, M. Z.: Short-term effects of controlling fossil-fuel soot, biofuel soot and gases, and methane on climate, Arctic ice, and air pollution health, J. Geophys. Res., 115, D14209, doi:10.1029/2009JD013795, 2010.

Jerrett, M., Burnett, R. T., Ma, R., Pope, C. A., Krewski, D., Newbold, K. B., Thurston, G., Shi, Y., Finkelstein, N., Calle, E. E., and Thun, M. J.: Spatial Analysis of Air Pollution and Mortality in Los Angeles, Epidemiology, 16(6), 727-736, 2005.

Kaufmann, U.: Schweizerische Statistik der erneuerbaren Energien, Ausgabe 2008, Dr. Eicher + Pauli AG im Auftrag des Bundesamtes für Energie BFE, Bundesamt für Energie BFE, Bern, Switzerland, 2009.

Kennedy, I. M.: The health effects of combustion-generated aerosols, Proceedings of the Combustion Institute, 31, 2757, 2007.

Kirchstetter, T. W., Novakov, T., and Hobbs, P. V.: Evidence that the spectral dependence of light absorption by aerosols is affected by organic carbon, J. Geophys. Res., 109, D21208, doi:10.1029/2004JD004999, 2004.
Lack, D. A. and Cappa, C. D.: Impact of brown and clear carbon on light absorption enhancement, single scatter albedo and absorption wavelength dependence of black carbon, Atmos. Chem. Phys., 10, 4207-4220, doi:10.5194/acp-10-4207-2010, 2010.

Lanz, V. A., Alfarra, M. R., Baltensperger, U., Buchmann, B., Hueglin, C., Szidat, S., Wehrli, M. N., Wacker, L., Weimer, S., Caseiro, A., Puxbaum, H., and Prevot, A. S. H.: Source attribution of submicron organic aerosols during wintertime inversions by advanced factor analysis of aerosol mass spectra, Environ. Sci. Technol., 42, 214-220, 2008.

Lukács, H., Gelencsér, A., Hammer, S., Puxbaum, H., Pio, C., Legrand, M., Kasper-Giebl, A., Handler, M., Limbeck, A., Simpson, D., and Preunkert, S.: Seasonal trends and possible sources of brown carbon based on 2-year aerosol measurements at six sites in Europe, J. Geophys. Res., 112(D23), D23S18, doi:10.1029/2006JD008151, 2007.

Moosmüller, H., Chakrabarty, R. K., and Arnott, W. P.: Aerosol Light Absorption and its Mea surement: A Review, J. Quant. Spectrosc. Ra., 110, 844-878, doi:10.1016/j.jqsrt.2009.02.035, 2009.

Oberdorster, G., Sharp, Z., Atudorei, V., Elder, A., Gelein, R., Lunts, A., Kreyling, W., and Cox, C.: Extrapulmonary translocation of ultrafine carbon particles following wholebody inhalation exposure of rats, J. Toxic Env. Health, 65, 1531, 2002.

Paatero, P. and Tapper, U.: Positive matrix factorization: a nonnegative factor model with optimal utilization of error estimates of data values, Environmetrics, 5, 111-126, 1994.

Peters, A., Liu, E., Verrier, R. L., Schwartz, J., Gold, D. R., Mittleman, M., Baliff, J., Oh, J. A., Allen, G., Monahan, K., and Dockery, D. W.: Air pollution and incidence of cardiac arrhythmia, Epidemiology, 11, 11-17, 2000.

Ramanathan, V. and Carmichael, G.: Global and regional climate changes due to black carbon, Nat. Geosci., 1, 221-227, 2008.

Sandradewi, J., Prevot, A. S. H., Szidat, S., Perron, N., Alfarra, M. R., Lanz, V. A., Weingartner, E., and Baltensperger, U.: Using aerosol light absorption measurements for the quantitative determination of wood burning and traffic emission contributions to particulate matter, Environ. Sci. Technol., 42, 3316-3323, 2008a.

Sandradewi, J., Prévôt, A. S. H., Weingartner, E., Schmidhauser, R., Gysel, M., and Baltensperger, U.: A study of wood burning and traffic aerosols in an Alpine valley using a multi-wavelength Aethalometer, Atmos. Environ., 42, 101-112, $2008 \mathrm{~b}$.

Sandradewi, J., Prévôt, A. S. H., Alfarra, M. R., Szidat, S., Wehrli, M. N., Ruff, M., Weimer, S., Lanz, V. A., Weingartner, E., Perron, N., Caseiro, A., Kasper-Giebl, A., Puxbaum, H., Wacker, L., and Baltensperger, U.: Comparison of several wood smoke markers and source apportionment methods for wood burning particulate mass, Atmos. Chem. Phys. Discuss., 8, 8091-8118, doi:10.5194/acpd-8-8091-2008, 2008c.

Subramanian, R., Roden, C. A., Boparai, P., and Bond, T. C.: Yellow Beads and Missing Particles: Trouble Ahead for FilterBased Absorption Measurements, Aerosol Sci. Tech., 41, 630637, 2007.

Szidat, S., Jenk, T. M., Synal, H.-A., Kalberer, M., Wacker, L., Hajdas, I., Kasper-Giebl, A., and Baltensperger, U.: Contributions of fossil fuel, biomass-burning, and biogenic emissions to carbonaceous aerosols in Zurich as traced by 14C, J. Geophys. Res., 111, D07206, doi:10.1029/2005JD006590, 2006. 
Szidat, S., Prevot, A. S. H., Sandradewi, J., Alfarra, M. R., Synal, H.-A., Wacker, L., and Baltensperger, U.: Dominant impact of residential wood burning on particulate matter in Alpine valleys during winter, Geophys. Res. Lett., 34, L05820, doi:10.1029/2006GL028325, 2007.

Weingartner, E., Saathof, H., Schnaiter, M., Streit, N., Bitnar, B., and Baltensperger, U.: Absorption of light by soot particles: Determination of the absorption coefficient by means of Aethalometers, J. Aerosol Sci., 34, 1445-1463, 2003.
Yang, M., Howell, S. G., Zhuang, J., and Huebert, B. J.: Attribution of aerosol light absorption to black carbon, brown carbon, and dust in China - interpretations of atmospheric measurements during EAST-AIRE, Atmos. Chem. Phys., 9, 2035-2050, doi:10.5194/acp-9-2035-2009, 2009. 